\title{
An APPlied Elasticity CoMmon SENSE Perspective AND THe OPTIMAL Design
}

\author{
OANTA, E.
}

Abstract: The paper presents aspects that support the concepts of rationality and optimality in applied elasticity. It considers several ideas employed in optimal design from the classic intuitive perspective as well as from the modern computer based approaches.

The original aspects of the paper consist of the general approach regarding the applied elasticity problems where the classic methods and the modern computer based methods must be equally considered in the design or evaluation of a structure. The presentation of the classical case studies use relevant figures and the computer based study employs an original and accurate FEM model which was calibrated by the use of experimental values.

The next studies will consider different optimization algorithms employed to evaluate the extents of the applied elasticity hypotheses used in analytic models.

Key words: elasticity, optimality, design, cases
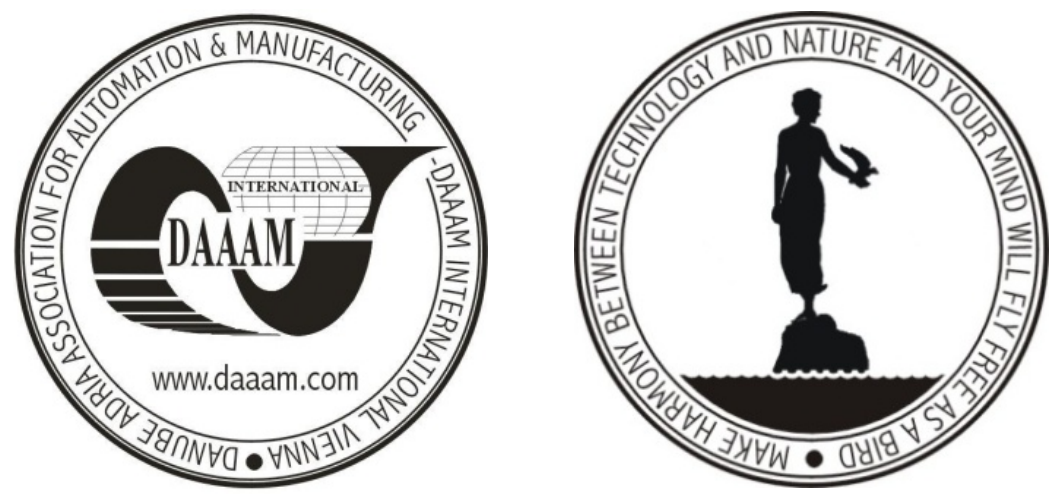

Authors' data: Assoc. Prof. Eng. Ph.D. Mech. Eng. Ph.D. Cyber., Oanta, E[mil], Constanta Maritime University, 104 Mircea cel Batran, 900663, Constanta, Romania, eoanta@yahoo.com

This Publication has to be referred as: Oanta, E[mil] (2009). An Applied Elasticity Common Sense Perspective and the Optimal Design, Chapter 40 in DAAAM International Scientific Book, 2009, pp. 385-396, B. Katalinic (Ed.), Published by DAAAM International, ISBN 978-3-901509-69-8, ISSN 1726-9687, Vienna, Austria DOI: 10.2507/daaam.scibook.2009.40 